\title{
Macrofauna inhabiting the sponge Paraleucilla magna (Porifera: Calcarea) in Rio de Janeiro, Brazil
}

\author{
ANDRÉ PADUA ${ }^{1}$, EMILIO LANNA ${ }^{1,2}$ AND MICHELLE KLAUTAU ${ }^{1}$ \\ ${ }^{1}$ Universidade Federal do Rio de Janeiro, Instituto de Biologia, Departamento de Zoologia, Avenida Carlos Chagas Filho, 373, CEP \\ 21941 - 902, Rio de Janeiro, RJ, Brazil, ${ }^{2}$ Universidade Federal da Bahia, Instituto de Biologia, Departamento de Biologia Geral, Rua \\ Barão de Jeremoabo, s/n, 40170-175, Campus de Ondina, Salvador, BA, Brasil
}

\begin{abstract}
Sponges (phylum Porifera) are important components of the benthic marine fauna known for their interactions with vertebrates and a large number of invertebrates seeking for food, shelter or substrate for attachment. Studies on this subject, however, were restricted only to the macrofauna inhabiting sponges of the class Demospongiae. In the present work, we describe the macrofauna associated with a calcareous sponge in Brazil, Paraleucilla magna. Individuals of this allegedly non-native species were monthly collected during one year in Rio de Janeiro (Brazil). Fifty-one taxa representing ten animal phyla were found associated with P. magna. The most frequent and abundant taxa were Crustacea, Mollusca, Polychaeta and Bryozoa, while echinoderms, cnidarians, ascidians, nemerteans, platyhelminthes and sponges were less frequent or even rare and less abundant. Juveniles of several taxa and pregnant females of Crustacea were found associated with P. magna, but these associations were not exclusive. The macrofauna associated with $\mathrm{P}$. magna did not present a clear seasonality, although it was possible to observe a change in the community composition alongside the year. The volume of the sponges was significantly related to the diversity index $\left(H^{\prime}\right)$ and number of taxa, but not with evenness $\left(J^{\prime}\right)$ and number of individuals. Our results show that $\mathrm{P}$. magna is used as a substrate for attachment and/or shelter by its associates and that most of these associations are just opportunistic. The data presented here reiterate a previous proposal that sponges are important biodiversity reservoirs and that they should be seriously considered in conservation programmes.
\end{abstract}

Keywords: association, ecology, Crustacea, Mollusca, Polychaeta, Bryozoa

Submitted 23 October 2012; accepted 16 November 2012; first published online 26 February 2013

\section{INTRDDUCTION}

Sponges (phylum Porifera) have long been considered living hotels' due to the great diversity and abundance of other taxonomic groups that are often found in association with them (Pearse, 1950; Klitgaard, 1995; Ribeiro et al., 2003). These associations represent a wide range of ecological interactions, facultative or obligatory, that range from mutualism to parasitism; however, the exact nature of many associations remains unclear (Wulff, 2006). Because sponges have bodies composed of an intricate network of canals, associated organisms may find substrate and shelter inside them (Çinar et al., 2002; Huang et al., 2008). As sponges are important components of benthic communities and interact with a wide range of organisms (Wulff, 2006; Becerro, 2008), they are considered to be important reservoirs of marine biodiversity (Cerrano et al., 2006).

Previous studies of sponge-associated fauna have been carried out in the North Atlantic Ocean (Frith, 1976; Biernbaum, 1981; Peattie \& Hoare, 1981; Klitgaard, 1995; Huang et al., 2008; Fiore \& Jutte, 2010), the Caribbean (Pearse, 1950; Villamizar \&

Corresponding author:

Michelle Klautau

Email: mklautau@biologia.ufri.br
Laughlin, 1991), the Mediterranean (Rützler, 1976; Koukouras et al., 1985, 1992, 1996; Ilan et al., 1994; Çinar et al., 2002), the Pacific Ocean (Long, 1968; Magnino et al., 1999; Beaulieu, 2001; Skilleter et al., 2005; Cerrano et al., 2006), and the Indian Ocean (Abdo, 2007). Only four studies have been performed in the South Atlantic Ocean: one in Argentina (Cuartas \& Excoffon, 1993) and three in Brazil (Duarte \& Nalesso, 1996; Ribeiro et al., 2003; Stofel et al., 2008). Other studies along the Brazilian coast have described associations between sponges and particular groups of organisms: parasitic crustaceans (Duarte \& Morgado, 1983), decapods (Bezerra \& Coelho, 2006), gammarids and caprellids (Serejo, 1998), copepods (Johnsson, 1998, 2000, 2002; Bispo et al., 2006), and polychaetes (Neves \& Omena, 2003).

With the exception of two studies that included hexactinellid sponges (Beaulieu, 2001; Fiore \& Jutte, 2010), almost all studies of sponge-associated fauna focused on the class Demospongiae. Only one study, conducted in Hampshire, UK, has investigated the associated fauna of a calcareous sponge (Frith, 1976). This study, however, found no fauna associated with either Sycon ciliatum (Fabricius, 1780) or Grantia compressa (Fabricius, 1780) and did not describe any organisms found with Leucosolenia botryoides (Ellis \& Solander, 1786) (Frith, 1976).

Paraleucilla magna Klautau et al., 2004 is a calcareous sponge found along the Brazilian coast (adjacent to the 

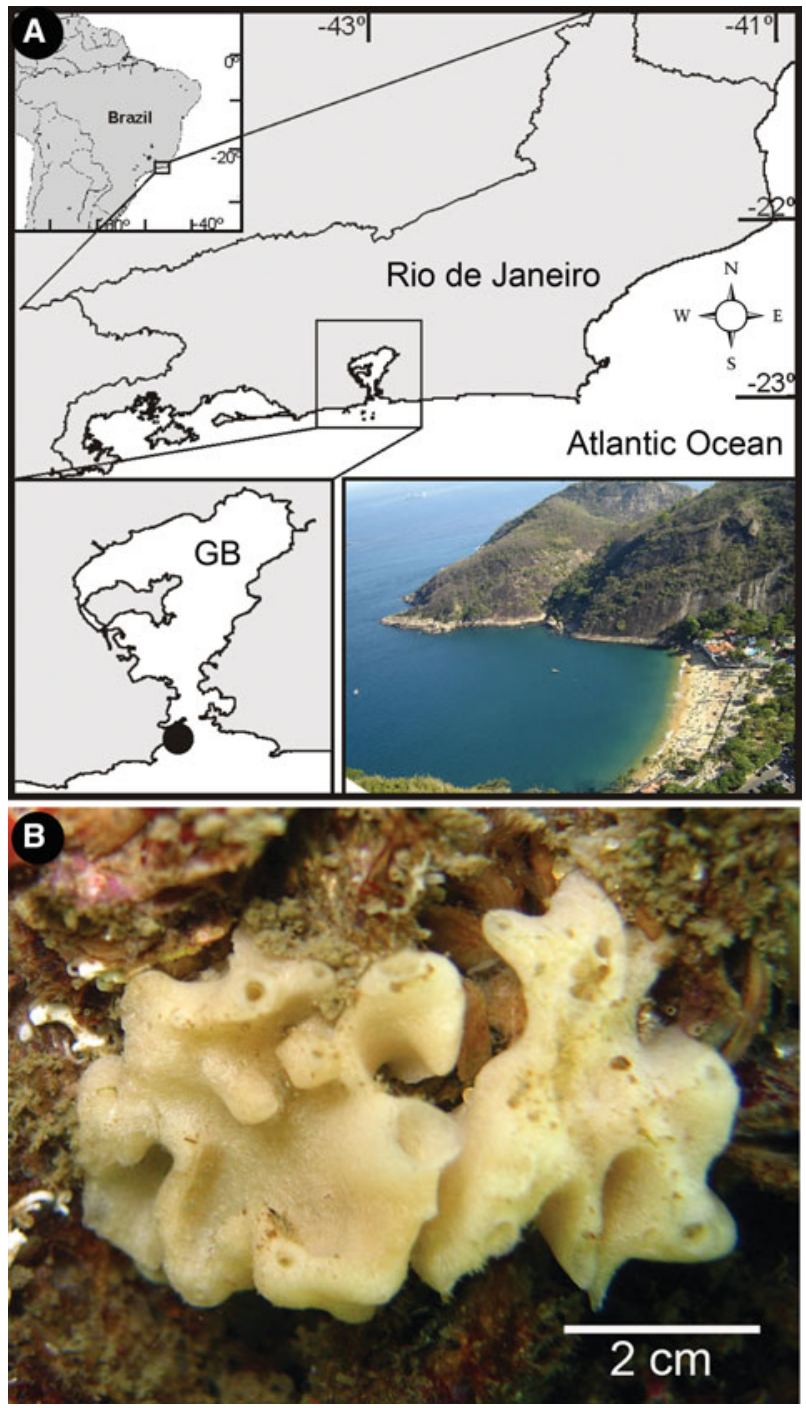

Fig. 1. (A) Location and aerial view of the study area. Vermelha Beach is located at the entrance of the eutrophic Guanabara Bay (GB) (black dot at inferior left corner) (map source: DIVA-GIS, Vermelha Beach photograph: F. Azevedo); (B) in vivo photograph of Paraleucilla magna.

Rio de Janeiro, São Paulo and Santa Catarina states) and in the Mediterranean (along the southern coast of Italy and around Malta). In both regions, it is considered to be a nonnative species, although its origin is still unknown (Klautau et al., 2004; Longo et al., 2007; Zammit et al., 2009; Gravili et al., 2010). It lives attached to hard substrates in photophilous or sciaphilous conditions and in pristine or polluted waters (Klautau et al., 2004; Longo et al., 2007; Gravili et al., 2010). This species has a leuconoid aquiferous system with a large atrial cavity and many canals that can be easily occupied by other organisms. In the original description of P. magna, crustaceans, echinoderms, and polychaetes were described as associating with this species (Klautau et al., 2004); however, there has been no subsequent research on its associated fauna. Therefore, to gain knowledge about the associated macrofauna of calcareous sponges, we investigated the composition of macrofauna inhabiting $P$. magna over the course of one year. The objectives of this study were to: (1) describe the species composition of the associated macrofauna of $P$. magna in Rio de Janeiro, south-western Atlantic; (2) investigate the influence of sponge volume on these associations; and (3) analyse possible seasonal variations of these associations.

\section{MATERIALS AND METHODS}

\section{Sampling}

Five specimens of P. magna (Figure $1 \mathrm{~B}$ ) were collected monthly throughout 2005 (except in February, when only four individuals were collected, and in April, when no collection occurred), totalling 54 specimens. All specimens were collected at Vermelha Beach ( $\left.22^{\circ} 57^{\prime} 18^{\prime \prime} \mathrm{S}-43^{\circ} 09^{\prime} 42^{\prime \prime} \mathrm{W}\right)$, in Rio de Janeiro, Brazil (Figure 1A; Lanna et al., 2007). Specimens were collected by snorkelling at o-4 $\mathrm{m}$ depth and were removed from the substrate with a knife. While underwater, each specimen was bagged individually (to avoid the escape of associated organisms) and then fixed and preserved in $93 \%$ ethanol. At the laboratory, the volume of each sponge was calculated by liquid displacement in a graduated cylinder (see Ribeiro et al., 2003; Lanna et al., 2007). Sponge specimens were then carefully fragmented under a stereomicroscope to remove the macrofauna $\left(>_{1} \mathrm{~mm}\right)$ that remained inside. Associated organisms of each sponge specimen were separated by morphotype within higher taxa and then identified to the lowest possible taxonomic level with the help of specialists.

\section{Data analysis}

We counted the total number of associated individuals and the total number of taxa to calculate species richness, frequency, abundance, density, diversity $\left(H^{\prime}\right)$, and Pielou's evenness $\left(J^{\prime}\right)$ (Ludwig \& Reynolds, 1988). To investigate whether the total volume of $P$. magna specimens collected each month (i.e. the sum volume of the five analysed individuals) could predict species richness, abundance, diversity and evenness, we performed linear regressions (Sokal \& Rohlf, 1995). The values of species richness, frequency, abundance, density, diversity $\left(H^{\prime}\right)$, and Pielou's evenness $\left(J^{\prime}\right)$ obtained for each month were used as replicates to test whether these attributes of the associated fauna varied between the dry (April to September) and rainy (October to March) seasons. The rainy season in Rio de Janeiro usually starts in September (Dereczynski et al., 2009), however, we have considered it as starting in October for our analyses because in 2005 (when the specimens were collected) the rainy period started only in that month (AlertaRio, 2011). All data were tested for normality and homoscedasticity prior to performing analyses of variance (ANOVAs). Temporal patterns in the community of associated fauna were assessed by means of a principal component analysis (PCA), in which the dimensionality of 21 species (the number of species that occurred in more than one month) was reduced to only two components (latent variables) representing the primary temporal patterns of dominant species. As most species were rare, and because many zeros were present in the data set (see Table 1), we applied a Hellinger transformation prior to analysis (see Legendre \& Gallager, 2001). PCA scores obtained for each month were used as replicates for the ANOVA to test whether these attributes of the associated fauna varied between the dry and rainy seasons (Jassby \& Powell, 1990). 
Table 1. Variation of the number of taxa associated with Paraleucilla magna. Colonies of Hydrozoa were not quantified, and their presence is marked with ' $\mathrm{P}$ '. Total number of individuals/colonies for each taxon and for each month and the total number of taxa of each phylum (within parentheses) are provided. (Por - Porifera, Cni - Cnidaria, Pla - Plathyhelminthes, Nem - Nematoda, Ann - Annelida, Art - Arthropoda, Mol - Mollusca, Bry Bryozoa, Ech - Echinodermata, Asc - Ascidiacea). $\left(^{*}\right)$ indicatess presence of juveniles.

\begin{tabular}{|c|c|c|c|c|c|c|c|c|c|c|c|c|c|}
\hline & Taxa & January & February & March & May & June & e July & y August & t September & r October & r November & r December & Total \\
\hline Por (1) & Leucosolenia sp. & 1 & o & o & o & o & o & o & o & o & o & o & 1 \\
\hline Cni (1) & Hydrozoa & 0 & $\mathrm{P}$ & 0 & 0 & $\mathrm{P}$ & 0 & $\mathrm{P}$ & 0 & 0 & $\mathrm{P}$ & o & \\
\hline Pla (1) & Enchiridium evelinae Marcus, 1949 & 1 & o & 0 & 0 & o & o & o & o & 0 & 0 & 0 & 1 \\
\hline Nem (1) & Unidentified nemertinean & 1 & 0 & 0 & 0 & 0 & 0 & 0 & 0 & 0 & 0 & 0 & 1 \\
\hline \multirow[t]{11}{*}{ Ann (11) } & Sabellidae sp.* & 1 & o & o & o & o & o & o & o & o & o & o & 1 \\
\hline & $\begin{array}{l}\text { Branchiomma luctuosum } \\
\quad \text { (Grube, 1869) }\end{array}$ & 1 & o & o & o & o & o & o & o & o & o & o & 1 \\
\hline & Phyllodocidae & 1 & o & o & o & o & o & o & o & o & o & o & 1 \\
\hline & Syllidae sp. 1 & 3 & o & o & o & o & o & o & o & o & o & o & 3 \\
\hline & Syllidae sp. 2 & 2 & o & o & o & 0 & o & o & o & 1 & o & o & 3 \\
\hline & Syllidae sp. 3 & 1 & 0 & 1 & 1 & 1 & 0 & o & o & o & 0 & 0 & 4 \\
\hline & Syllidae sp. 4 & o & 1 & 0 & 0 & 0 & 0 & 0 & 0 & 0 & 0 & o & 1 \\
\hline & Syllidae sp. 5 & o & o & o & o & 1 & o & o & o & o & o & o & 1 \\
\hline & Syllidae sp. 6 & o & o & o & o & o & 1 & o & o & o & o & o & 1 \\
\hline & Syllidae sp. 7 & o & o & o & o & o & o & 1 & o & 0 & 0 & 0 & 1 \\
\hline & Naineris setosa (Verrill, 1900) & o & o & o & 0 & 0 & o & o & o & o & o & 1 & 1 \\
\hline \multirow[t]{17}{*}{ Art (17) } & Stenothoidae & 1 & o & o & 2 & o & 16 & 6 & 7 & 3 & 21 & 2 & 58 \\
\hline & Melitidae sp. & 0 & o & o & 0 & o & o & 2 & 0 & 0 & 1 & 0 & 3 \\
\hline & $\begin{array}{l}\text { Quadrimaera quadrimana (Dana, } \\
\text { 1852) }\end{array}$ & 1 & o & o & o & o & o & o & 1 & o & 6 & o & 8 \\
\hline & Elasmopus pectenicrus (Bate, 1862) & 6 & o & 1 & 2 & 1 & 2 & o & o & o & o & 3 & 15 \\
\hline & Dulichiella appendiculata (Say, 1818) & 3 & 0 & o & o & 0 & 0 & 0 & 0 & 0 & 0 & 0 & 3 \\
\hline & Podoceridae sp. & o & o & o & o & 0 & 0 & 0 & 1 & 0 & 0 & 5 & 6 \\
\hline & Corophiidae & o & 0 & o & o & 0 & 0 & 0 & o & o & 1 & o & 1 \\
\hline & Cymadusa filosa Savigny, 1816 & 3 & o & o & 2 & o & 4 & 10 & 3 & 10 & 18 & 1 & 51 \\
\hline & Isopoda & o & o & o & o & o & o & o & o & 1 & o & o & 1 \\
\hline & Carpias sp. & o & o & 0 & 0 & 0 & 0 & 0 & 0 & 0 & 3 & 0 & 3 \\
\hline & Mithrax sp.* & o & o & o & o & o & o & 2 & o & o & 0 & o & 2 \\
\hline & $\begin{array}{l}\text { Epialtus bituberculatus Milne } \\
\quad \text { Edwards, } 1834\end{array}$ & o & o & o & o & o & o & 1 & o & o & o & o & 1 \\
\hline & $\begin{array}{l}\text { Micropanope nuttingi } \\
\quad \text { (Rathbun, 1898) }\end{array}$ & o & o & o & 1 & o & o & 1 & o & o & o & o & 2 \\
\hline & Petrolisthes armatus (Gibbes, 1850) & o & o & o & o & o & 0 & o & o & o & 1 & o & 1 \\
\hline & Pachycheles monilifer (Dana, 1852) & o & o & o & o & o & o & o & o & o & o & 2 & 2 \\
\hline & $\begin{array}{l}\text { Pachycheles laevidactylus Ortmann, } \\
1892\end{array}$ & 0 & o & o & o & 2 & 5 & 10 & 9 & 4 & 3 & 2 & 35 \\
\hline & Pycnogonida sp. & 2 & o & o & o & 0 & o & 0 & 0 & 0 & 0 & 0 & 2 \\
\hline \multirow[t]{9}{*}{ Mol (9) } & Bivalvia sp. 1 & o & o & 0 & 1 & 25 & 9 & 3 & 1 & 2 & 1 & 0 & 42 \\
\hline & Bivalvia sp.2 & 0 & 0 & 0 & 1 & 0 & 0 & 0 & 0 & 0 & 0 & 0 & 1 \\
\hline & Bivalvia sp. 3 & 0 & o & o & o & 1 & 3 & o & 1 & 1 & 1 & 2 & 9 \\
\hline & Mytilidae sp.* & 0 & o & o & 3 & 1 & 2 & o & 1 & 1 & 2 & o & 10 \\
\hline & $\begin{array}{l}\text { Sphenia fragilis (H. Adams \& } \\
\quad \text { A. Adams, 1854) }\end{array}$ & o & o & o & 1 & o & o & o & 0 & o & o & o & 1 \\
\hline & Arca sp. & o & o & o & o & o & o & o & o & o & 1 & o & 1 \\
\hline & Gastropoda sp. & o & o & o & o & o & 0 & o & o & o & 1 & o & 1 \\
\hline & Calyptraeidae & 1 & o & 1 & o & o & 1 & o & 1 & o & 3 & o & 7 \\
\hline & Crepidula sp. & o & o & 1 & 1 & o & o & o & o & o & o & o & 2 \\
\hline \multirow[t]{3}{*}{ Bry (3) } & Bugula neritina (Linnaeus, 1758) & 1 & 0 & 2 & 3 & 4 & 0 & o & o & o & 0 & o & 10 \\
\hline & $\begin{array}{l}\text { Scrupocellaria aff. reptans } \\
\quad \text { (Linnaeus, } 1758 \text { ) }\end{array}$ & o & 1 & 1 & 7 & 5 & 2 & 1 & o & o & 1 & 2 & 20 \\
\hline & Hippoporina sp. & o & o & 1 & o & o & 0 & o & o & o & o & o & 1 \\
\hline \multirow[t]{4}{*}{ Ech (4) } & $\begin{array}{l}\text { Ophiactis savignyi (Müller \& } \\
\text { Troschel, 1842) }\end{array}$ & 1 & o & o & o & o & o & 1 & o & o & o & 1 & 3 \\
\hline & Ophiactis lymani Ljungman, 1872 & 6 & o & 0 & 0 & 0 & 0 & o & o & o & 0 & 3 & 9 \\
\hline & $\begin{array}{l}\text { Amphipholis squamata } \\
\text { (Delle Chiaje, 1828) }\end{array}$ & o & o & o & o & 0 & 0 & 0 & 0 & 0 & 1 & 0 & 1 \\
\hline & $\begin{array}{l}\text { Lytechinus variegatus* (Lamarck, } \\
\text { 1816) }\end{array}$ & o & o & o & o & o & o & o & 1 & o & o & o & 1 \\
\hline \multirow[t]{3}{*}{$\operatorname{Asc}(3)$} & Didemnum sp. 1 & 1 & 1 & 2 & 1 & 1 & 0 & o & 0 & 0 & 1 & 1 & 8 \\
\hline & Didemnum sp. 2 & 0 & 0 & 2 & 2 & 0 & 1 & 0 & 0 & 0 & 0 & 0 & 5 \\
\hline & Botrylloides giganteum (Pérès, 1949) & o & o & o & o & o & 1 & o & o & o & o & 1 & 2 \\
\hline \multicolumn{2}{|c|}{ Number of specimens } & 38 & 3 & 12 & 28 & 42 & 47 & 38 & 26 & 23 & 66 & 26 & 349 \\
\hline
\end{tabular}


Table 2. Summary of the ecological data collected each month.

\begin{tabular}{|c|c|c|c|c|c|c|c|c|c|c|c|c|}
\hline & January & February & March & May & June & July & August & September & October & November & December & Year \\
\hline Number of species & 20 & 4 & 9 & 14 & 11 & 12 & 12 & 10 & 8 & 18 & 13 & 51 \\
\hline Number of specimens & 38 & 3 & 12 & 28 & 42 & 47 & 38 & 26 & 23 & 66 & 26 & 349 \\
\hline Species diversity $\left(H^{\prime}\right)$ & 2.7 & 1.4 & 2.1 & 2.4 & 1.5 & 2.0 & 2.1 & 1.8 & 1.7 & 2.1 & 2.4 & 3.0 \\
\hline Evenness $\left(J^{\prime}\right)$ & 0.9 & 1.0 & 1.0 & 0.9 & 0.6 & 0.8 & 0.8 & 0.8 & 0.8 & 0.7 & 0.9 & 0.4 \\
\hline Total volume of sponges $\left(\mathrm{cm}^{3}\right)$ & 115 & 18 & 8 & 11 & 15 & 38 & 52 & 24 & 12 & 21 & 67 & 381 \\
\hline Density (ind. $\mathrm{cm}^{-3}$ ) & 0.3 & 0.2 & 1.5 & 2.5 & 2.8 & 1.1 & 0.7 & 1.1 & 1.9 & 3.1 & 0.4 & 0.9 \\
\hline
\end{tabular}

\section{RESULTS}

\section{Associated macrofauna}

A total of 349 individuals, representing 51 species and 10 phyla, were identified living in association with the 54 analysed specimens of $P$. magna (Table 1 ). The mean species richness of associated taxa was 11.9 species/month ( \pm 4.4 ; Table 2 ). Arthropoda (mostly Crustacea) showed the highest species richness (17 species); followed by Annelida, with 11 taxa of polychaetes; and Mollusca, with nine species (Table 1). The species diversity of the total associated macrofauna was high $\left(H^{\prime}=3.0\right)$, but the total evenness was low $\left(J^{\prime}=0.4\right)$ (Table 2$)$.

The most abundant higher taxa were Arthropoda (54\%), Mollusca (21\%), and Bryozoa (9\%) (Figure 2), while the most frequent were Arthropoda, Annelida (Polychaeta), Mollusca, and Bryozoa, present in $72.2 \%, 57.4 \%, 48.2 \%$, and $40.7 \%$ of the sponges, respectively (Figure 3). Chordata (Ascidiacea), Cnidaria (Hydrozoa), and Echinodermata were found less frequently (present in $22.2 \%, 14.8 \%$, and $12.9 \%$ of the sponges, respectively), while Platyhelminthes, Nemertea, and Porifera were found in only $1.8 \%$ of specimens (Figure 3 ). The density of associated individuals was highest in November and June (3.1 and 2.8 ind. $\mathrm{cm}^{-3}$ ) and lowest in February and January ( 0.2 and 0.3 ind. $\mathrm{cm}^{-3}$ ). This variation was not significantly different between the dry and rainy seasons (Table $3 \mathrm{~A}$ ).

Juvenile representatives of Crustacea (Mithrax sp.), Polychaeta (Sabellidae sp., Syllidae spp.), Mollusca (Mytilidae sp.), and Echinodermata (Lytechinus variegatus)

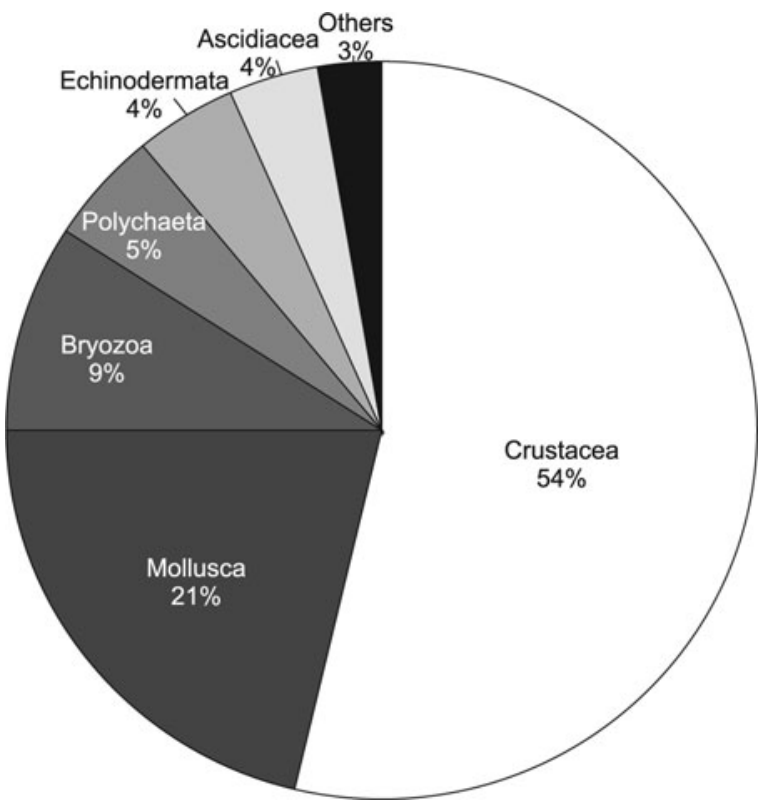

Fig. 2. Proportion of the higher taxa associated with Paraleucilla magna.

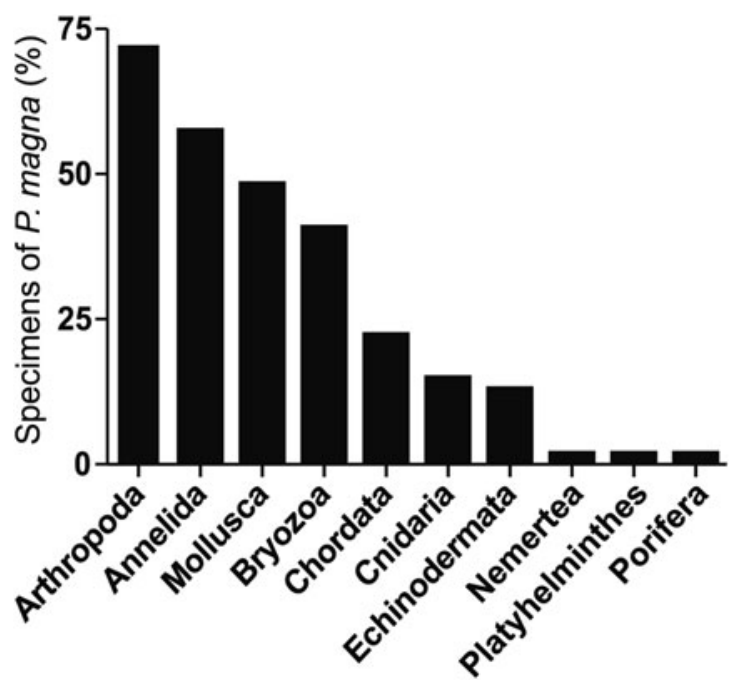

Fig. 3. Frequency (\%) of the phyla associated with Paraleucilla magna.

were found living associated with P. magna. In addition, pregnant crustacean females were also frequently observed.

\section{Volume}

Total sponge volume (i.e. the sum volume of sponges collected each month; Table 2) did not differ between seasons

Table 3. Summary of the ANOVA testing the influence of seasonality (dry versus rainy seasons) on community descriptors during the study period $(d f=$ degrees of freedom; Sum $\mathrm{Sq}=$ sum of squares; Mean $\mathrm{Sq}=$ mean of squares; $\operatorname{Pr}>\mathrm{F}=P$ value associated with the $\mathrm{F}$ statistic; $\left.{ }^{*} P<0.05\right)$.

\begin{tabular}{|c|c|c|c|c|c|}
\hline & df & Sum Sq & Mean Sq & $F$ value & $\operatorname{Pr}>\mathrm{F}$ \\
\hline \multicolumn{6}{|c|}{ (A) Density of associated individuals } \\
\hline Season & 1 & 0.552 & 0.5520 & \multirow[t]{2}{*}{0.4402} & \multirow[t]{2}{*}{0.5236} \\
\hline Residuals & 9 & 11.285 & 1.2539 & & \\
\hline \multicolumn{6}{|c|}{ (B) Sponge volume } \\
\hline Season & 1 & 404.600 & 404.6000 & \multirow[t]{3}{*}{0.3559} & \multirow[t]{3}{*}{0.5655} \\
\hline Residuals & 9 & 10232.800 & 1137.0000 & & \\
\hline \multicolumn{4}{|c|}{ (C) Species richness } & & \\
\hline Season & 1 & 0.109 & 0.1091 & \multirow[t]{2}{*}{0.0049} & \multirow[t]{2}{*}{0.9455} \\
\hline Residuals & 9 & 198.800 & 22.0889 & & \\
\hline \multicolumn{6}{|c|}{ (D) Number of associated individuals } \\
\hline Season & 1 & 186.380 & 186.3800 & \multirow[t]{2}{*}{0.5943} & \multirow[t]{2}{*}{0.4605} \\
\hline \multicolumn{4}{|c|}{ (E) Diversity $\left(\mathrm{H}^{\prime}\right)$} & & \\
\hline Season & 1 & 0.032 & 0.03292 & \multirow[t]{2}{*}{0.1850} & \multirow[t]{2}{*}{0.6773} \\
\hline $\begin{array}{l}\text { Residuals } \\
\text { (F) Evenn }\end{array}$ & 9 & 1.601 & 0.17797 & & \\
\hline Season & 1 & 0.025 & 0.02579 & \multirow[t]{2}{*}{2.6065} & \multirow[t]{2}{*}{0.1409} \\
\hline Residuals & 9 & 0.089 & 0.00989 & & \\
\hline
\end{tabular}




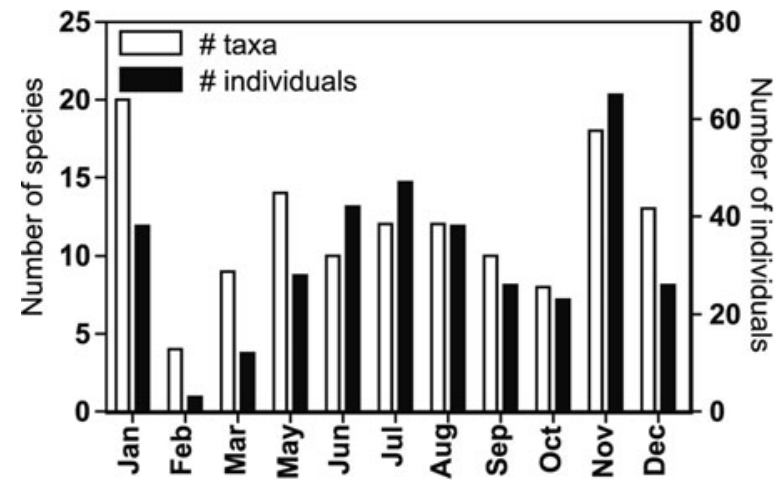

Fig. 4. Monthly variation of the number of species and individuals associated with Paraleucilla magna.

(Table $3 \mathrm{~B}$ ) but was significantly correlated to both species diversity $\left(H^{\prime}\right)\left(\mathrm{R}^{2}=0.43, \mathrm{df}=10, P=0.027\right.$, Figure $\left.5 \mathrm{~A}\right)$ and the number of taxa (species richness) $\left(\mathrm{R}^{2}=0.37, \mathrm{df}=\right.$ $10, P=0.04$, Figure $5 \mathrm{~B}$ ), indicating that larger sponges contained a higher variety of taxa and a higher diversity of species. Nonetheless, regression analyses indicated that the total volume in each month did not correlate to either the Pielou evenness index $\left(J^{\prime}\right)\left(\mathrm{R}^{2}=0.04, \mathrm{df}=10, P=0.52\right.$, Figure ${ }_{5} \mathrm{C}$ ) or the total number of associated individuals (abundance) $\left(\mathrm{R}^{2}=0.03, \mathrm{df}=10, P=0.56\right.$, Figure $\left.{ }_{5} \mathrm{D}\right)$.

\section{Seasonality}

The periods of lowest and highest species richness $($ February $=4$; January $=20$, respectively) coincided with the months of lowest and highest diversity $\left(H^{\prime}\right)$ (February $H^{\prime}=1.4$; January $-H^{\prime}=2.7$ ) (Table 2). Abundance (i.e. the number of associated individuals) was lowest in February (only three individuals), and highest in November (66 individuals) (Table 1; Figure 4). The evenness of associated macrofauna tended to be high, being highest in February and March $\left(J^{\prime}=1.0\right)$ and lowest in June $\left(J^{\prime}=0.6\right)$ (Table 2). None of these community descriptors differed significantly between the dry and rainy seasons (Table $3 \mathrm{C}-\mathrm{F}$ ).

Seasonal changes in the community of macrofauna associated with $P$. magna were analysed using biplots based on PCA (Figure 6A). The total amount of variation explained by the first two scores (corresponding to the first two principal components) was $56.9 \%$. The PCA biplot did not show a clear seasonal difference between the dry and rainy seasons. Nevertheless, three groups of species were partially distinguished by the analysis:

Group A (formed mainly by the bryozoan Scrupocellaria aff. reptans (Linnaeus, 1758) and the ascidians Didemnum sp. 1 and Bugula neritina (Linnaeus, 1758)), which appeared between February and June;

Group B (formed mainly by the mollusc Bivalvia sp.1 and the crustaceans Pachycheles laevidactylus Ortmann, 1892 and Cymadusa filosa Savigny, 1816) that appeared from July to November;

Group C (formed mainly by the ophiuroid Ophiactis lymani Ljungman, 1872) comprised only one species and was found exclusively in January and December.

Scores of the first component (PC1), which account for $38.7 \%$ of the variation, did not differ significantly between the dry and rainy seasons (Figure 6B; Table 4A). However, the scores of the second component ( $\mathrm{PC}_{2}$ ), which account for $18.2 \%$ of the variation, were significantly different between these seasons (Figure 6C; Table $4 \mathrm{~B}$ ).

\section{DISCUSSIDN}

Paraleucilla magna exhibited moderate-to-low richness of associated macrofauna (51 species) relative to all other

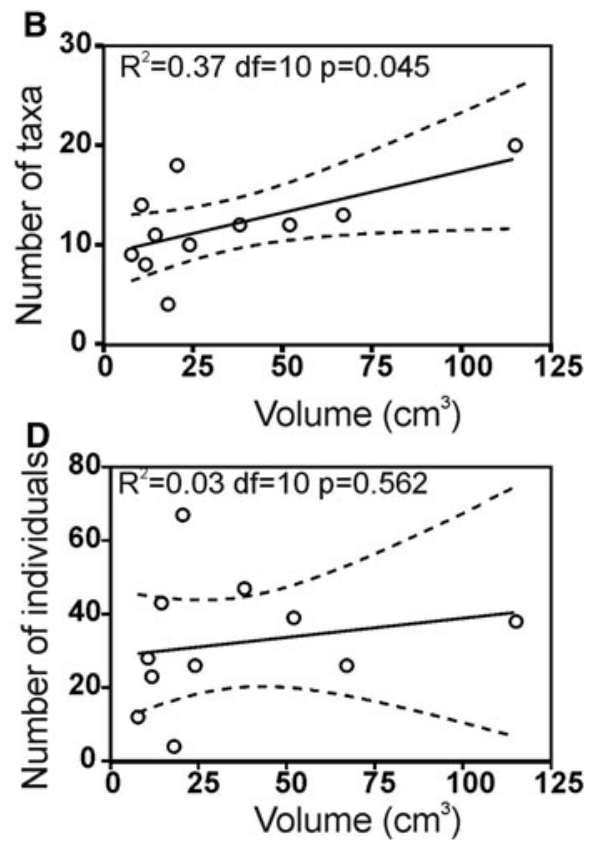

Fig. 5. Quantitative analyses of the macrofauna associated with Paraleucilla magna. Linear regression between sponge volume and (A) species diversity ( $\left.\mathrm{H}^{\prime}\right)$; (B) number of taxa; (C) evenness ( $\left.\mathrm{J}^{\prime}\right)$; (D) number of individuals. The dotted lines indicate the $95 \%$ confidence intervals. 

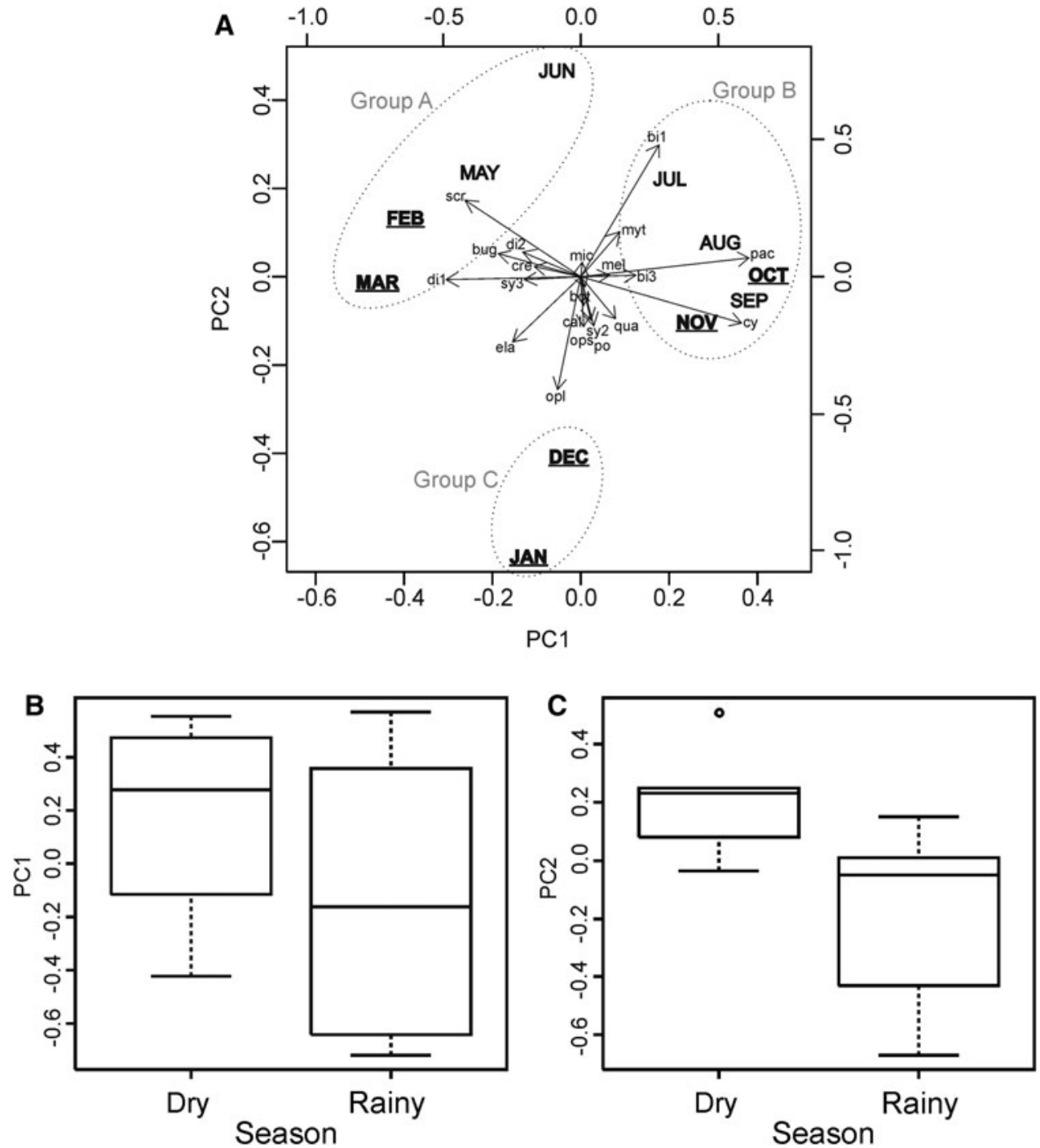

Fig. 6. Principal component analysis (PCA) of the associated fauna of Paraleucilla magna: (A) biplot representation of the PCA showing both observations (months) and variables (species) in the same graph. The left and bottom axes use the unity for observations, while the top and right axes are graduated according to the first two principal components of the original variables. PC1 accounts for $38.7 \%$ of the total variation, while PC 2 accounts for $18.2 \%$. Months are represented by upper case letters (Species: bi1, Bivalvia sp. 1; bi3, Bivalvia sp. 3; bot, Botrylloides giganteum; bug, Bugula neritina; cal, Calyptraeidae; cre, Crepidula sp.; cym, Cymadusa filosa; di1, Didemnum sp. 1; di2, Didemnum sp. 2; ela, Elasmopus pectenicrus; mel, Melitidae sp.; mic, Micropanope nuttingi; myt, Mytilidae sp.; opl, Ophiactis lymani; ops, Ophiactis savignyi; pac, Pachycheles laevidactylus; pod, Podceridae sp.; qua, Quadrimaera quadrimana; scr, Scrupocellaria aff. reptans; sy2, Syllidae sp. 2; sy3, Syllidae sp.); (B and C) box plots of the scores of (B) the first principal component (PC1) and (C) the second principal component ( $\left.\mathrm{PC}_{2}\right)$ in the dry and rainy seasons. Each box displays the median, upper and lower quartiles of the distribution of sponge volume per month. Box whiskers represent the maximum and minimum range, while empty circles show outliers.

sponge species investigated to date (48 Demospongiae and two Hexactinellida). Demosponges, for example, yielded an average of 95.5 associated taxa per species $( \pm 162.2$ of standard

Table 4. Summary results of the analysis of variance carried out on the scores of the two main principal components testing the seasonality (dry versus rainy seasons) of the associated fauna during the studied period $(\mathrm{df}=$ degrees of freedom; Sum $\mathrm{Sq}=$ sum of squares; Mean $\mathrm{Sq}=$ mean of squares; $\operatorname{Pr}>\mathrm{F}=P$ value associated with the $\mathrm{F}$ statistic; $\left.{ }^{*} P<0.05\right)$.

\begin{tabular}{lcclll}
\hline & df & Sum Sq & Mean Sq & F value & Pr $>$ F \\
\hline (A) PC1 & & & & & \\
Season & 1 & 0.2126 & 0.2126 & 0.9401 & 0.3576 \\
Residuals & 9 & 2.0353 & 0.2261 & & \\
$\begin{array}{l}\text { (B) PC2 } \\
\text { Season }\end{array}$ & 1 & 0.3972 & 0.3972 & 5.4382 & $0.0446^{*}$ \\
Residuals & 9 & 0.6573 & 0.0730 & & \\
\hline
\end{tabular}

deviation), with a minimum of two and a maximum of 809 taxa (e.g. Westinga \& Hoetjes, 1981; Villamizar \& Laughlin, 1991; Cuartas \& Excoffon, 1993; Klitgaard, 1995; Koukouras et al., 1996; Betancourt-Lozano et al., 1998; Magnino et al., 1999; Çinar et al., 2002; Neves \& Omena, 2003; Ribeiro et al., 2003; Abdo, 2007; Huang et al., 2008). In P. magna, Crustacea was the most abundantly represented group of associated organisms (54\%), followed by Mollusca (21\%), and Bryozoa (9\%). In other studied sponges, Crustacea was also one of the two most abundantly represented groups, being present in $80 \%$ of the sponge species examined, followed by Polychaeta (60\%) and Echinodermata (24\%). Molluscs were the second most abundant group in P. magna (21\%); however, this is not a common occurrence, as they have been identified as a dominant group in only a few species of sponges ( $8 \%$ of those examined so far; Long, 1968; Peattie \& Hoare, 1981; Kligaard, 1995; Koukouras et al., 1996). The same pattern 
occurs with Bryozoa, which was the third most abundant taxon in P. magna but is not considered to be among the two most abundant organisms in other studied sponges. However, bryozoans were the second most dominant group (12.8\% of the total number of taxa) found in demosponges of the Faroe Island, north-eastern Atlantic (Klitgaard, 1995) and, as in the present study, Klitgaard (1995) also found that most of the bryozoans were attached to the outer surface of the sponges. Associations between sponges and bryozoans may be related to the fact that sponges may provide suitable substrate to bryozoans in habitats of otherwise limited substrate availability, as noted by Klitgaard (1995).

A study of the associated fauna of the demosponge Mycale microsigmatosa Arndt, 1927 was performed at the same location of the present study (Ribeiro et al., 2003). Both $P$. magna and M. microsigmatosa exhibit associated macrofauna of similar species richness ( 51 and 75 species, respectively) and composition. However, the differences observed in taxonomic composition between these two sympatric species can be explained by the different sample sizes of each study. In the present study, we analysed 54 specimens of $P$. magna, while Ribeiro et al. (2003) analysed 19 specimens of M. microsigmatosa. Species diversity was the same in $P$. magna and M. microsigmatosa $\left(H^{\prime}=3.0\right)$, while evenness was lower in P. magna $\left(J^{\prime}=0.4\right.$, versus $J^{\prime}=0.7$ for $M$. microsigmatosa). The difference in evenness values between both species may be also due to sampling differences. In the present work, several collections throughout the year were made, while Ribeiro et al. (2003) made only one collection. The most striking difference between these two species is in the total number of associated individuals (abundance): P. magna was associated with 349 individuals ( 0.9 ind. $\mathrm{cm}^{-3}$ ), while $M$. microsigmatosa was associated with 2235 (13 ind. $\left.\mathrm{cm}^{-3}\right)$. If we consider that both sponges have the same type of aquiferous system (leuconoid), we could expect similar internal canals and, consequently, similar associated macrofauna. Nonetheless, P. magna has a large atrium, while $M$. microsigmatosa has only canals, and whereas $P$. magna is massive, M. microsigmatosa is an incrustant sponge. In addition, the external surface of P. magna is full of folds, while M. microsigmatosa has a smoother surface. Despite these morphological characteristics that seem to characterize $P$. magna as a better host, $M$. microsigmatosa is host to more associated organisms. A possible explanation for this difference in macrofauna abundance is the presence of chemicals that might reduce predation in M. microsigmatosa and, consequently, provide more protection for its associated macrofauna. Although this hypothesis has not been tested, $M$. microsigmatosa does produce a series of compounds, some of which inhibit microorganism proliferation (Compagnone et al., 1999; Marinho et al., 2009, 2010; Santos et al., 2010). The potential importance of sponge allelochemicals in influencing the composition and abundance of associated fauna has already been pointed out (Koukouras et al., 1992; Skilleter et al., 2005). A good example can be found in the work of Betancourt-Lozano et al. (1998), which describes a significant relationship between inquilinism and the antibiosis activity of Aplysina fistularis (Pallas, 1766) in Mexico.

Paraleucilla magna shares with $M$. microsigmatosa at least three associated species, two of which (the ophiuroids Amphipholis squamata and Ophiactis savignyi) occur commonly in other sponge species (Table 5). Although echinoderms have been found in only $12.9 \%$ of the analysed specimens of $P$. magna, they (particularly Ophiuroidea) are commonly found in demosponges (Wendt et al., 1985; Duarte \& Nalesso, 1996; Betancourt-Lozano et al., 1998; Ribeiro et al., 2003; Clavico et al., 2006; Abdo, 2007) and other benthic organisms, such as bryozoans (Morgado \& Tanaka, 2001). Associations of Ophiactis savigny and $O$. lymani with marine organisms are apparently common. For example, both species have been described as common epifauna on the tubes of the polychaete Phyllochaetopterus socialis Claparède, 1869 (Nalesso et al., 1995), on the octocoral Carijoa riisei (Duchassaing \& Michelotti, 1860) (Neves et al., 2007), and on algae (Mladenov \& Emson, 1988). The frequent association of these ophiuroid species with varied taxa (algae, polychaetes, corals and sponges) may indicate that these associations (including with $P$. magna) are only occasional or opportunistic. These ophiuroids may seek out these organisms only for protection or food (Klitgaard, 1995).

The volume of $P$. magna was positively related only to species diversity and number of taxa (richness). These relationships have already been observed in other sponge species: S. foetidus (for species diversity) and M. microsigmatosa, M. angulosa, S. foetidus, and Spheciospongia vesparium

Table 5. Species associated with Paraleucilla magna that were already found associated with other sponge species. 1 - Mycale microsigmatosa (Rio de Janeiro, Brazil; Ribeiro et al., 2003); 2 - Mycale angulosa (São Paulo, Brazil; Duarte \& Nalesso, 1996); 3 - Dysidea robusta Vilanova \& Muricy, 2001 (Rio de Janeiro, Brazil; Serejo, 1998); 4 - Topsentia sp. (south-eastern United States; Fiore \& Jutte, 2010); 5 - Ircinia campana (Lamarck, 1814) (south-eastern United States; Fiore \& Jutte, 2010); 6 - Sarcotragus foetidus (Turkish Aegean coast; Çinar et al., 2002); 7 - Aplysina lacunosa (Pallas, 1766) (Venezuelan Caribbean; Villamizar \& Laughlin, 1991); 8 - Sarcotragus fasciculatus (Pallas, 1766) (North Aegean Sea; Koukouras et al., 1985); 9 - Sidonops corticostylifera (Hajdu, Muricy, Custodio, Russo \& Peixinho, 1992) (Rio de Janeiro, Brazil; Clavico et al., 2006); 10 - Halichondria panicea (Pallas, 1766) (Menai Strait, UK; Peattie \& Hoare, 1981); 11 - Ircinia strobilina (Lamarck, 1816) (Bimini, Bahamas; Pearse, 1950); 12 - Geodia macandrewii Bowerbank, 1858 (Faroe Islands; Klitgaard, 1995); 13 - Cliona varians (Duchassaing \& Michelotti, 1864) (Stofel et al., 2008).

\begin{tabular}{|c|c|c|c|c|c|c|c|c|c|c|c|c|c|}
\hline Associated species & $\mathbf{1}$ & 2 & 3 & 4 & 5 & 6 & 7 & 8 & 9 & 10 & 11 & 12 & 13 \\
\hline \multicolumn{14}{|l|}{ Crustacea } \\
\hline Elasmopus pectenicrus & $\mathrm{x}$ & & & & & & & & & & & & \\
\hline Quadrimaera quadrimana & & & $\mathrm{x}$ & & & & & & & & & & \\
\hline Dulichiella appendiculata & & & $\mathrm{x}$ & $\mathrm{x}$ & $\mathrm{x}$ & & & & & & & & \\
\hline \multicolumn{14}{|l|}{ Cymadusa filosa } \\
\hline Echinodermata & & & & & & & & & & & & & \\
\hline Amphipholis squamata & $\mathrm{x}$ & $\mathrm{x}$ & & & & & & $\mathrm{x}$ & & $\mathrm{x}$ & & $\mathrm{x}$ & \\
\hline Ophiactis lymani & & $\mathrm{x}$ & & & & & & & & & & & $\mathrm{x}$ \\
\hline Ophiactis savignyi & $\mathrm{x}$ & $\mathrm{x}$ & & & & $\mathrm{x}$ & $\mathrm{x}$ & & $\mathrm{x}$ & & $\mathrm{x}$ & & \\
\hline
\end{tabular}


(Lamarck, 1815) (for richness) (Westinga \& Hoetjes, 1981; Duarte \& Nalesso, 1996; Çinar et al., 2002; Ribeiro et al., 2003). In $P$. magna, higher volumes can reflect a diverse array of microhabitats inside the sponge, such as more and larger folds, or larger atria and oscula, which could accommodate larger organisms and, consequently, a higher diversity of taxa. On the other hand, no relationship between volume and number of individuals was observed in P. magna, and this relationship has also not been observed in several demosponge species (four from the Aegean Sea, Koukouras et al., 1992; and two from Australia, Skilleter et al., 2005). In P. magna, large volumes might provide habitat for other species that could then compete with the fauna that live in smaller sponges. The fact that we found associated organisms in a great variety of sponge volumes (from $0.3 \mathrm{~cm}^{3}$ to $37 \mathrm{~cm}^{3}$ ) suggests that this species is rapidly colonized by organisms in the environment.

In the present study, no significant seasonal variation in community descriptors of the fauna associated with $P$. magna (species richness, number of individuals, species diversity $\left(H^{\prime}\right)$, and evenness index $\left.\left(J^{\prime}\right)\right)$ was detected. This lack of seasonal variation can be explained, in part, by the relationship of some of these descriptors with sponge volume (as described above). As neither sponge volume nor the community descriptors exhibit variation between the dry and rainy seasons (see Table 2), the absence of any seasonal trend could be expected. However, it is important to consider that sample size, differences in the sponges volume collected each month and a possible atypical year could have influenced these results.

Although the PCA biplot (Figure 6A) suggests no seasonal variation between the dry and rainy seasons, the second component $\left(\mathrm{PC}_{2}\right)$ scores differed significantly between seasons. This latter result indicates that some environmental change (in features such as salinity, temperature, or food availability) might influence the composition of the associated fauna community. However, the causes of variation explained by the first component $\left(\mathrm{PC}_{1}\right)$ are unknown and not likely to be correlated with season. On the other hand, we observed three groups of species that occupied $P$. magna in temporal succession (Groups A, B, and C). The establishment of these groups may reflect the life cycle of the associated organisms.

We frequently found pregnant crustacean females and juveniles of several taxa (molluscs, crustaceans, echinoderms, and polychaetes) inhabiting $P$. magna that probably used their host as a temporary shelter during vulnerable periods of their life cycle (i.e. reproductive or juvenile stages). This kind of relationship can be characterized as opportunistic. Ribeiro et al. (2003) and Abdo (2007) also found pregnant females, juveniles or reproductively active individuals associated with M. microsigmatosa and two Haliclona species in Brazil and Australia, respectively.

These findings suggest that sponges may be important shelters during some stages of the life cycle of many invertebrates, enhancing their survival. All of these aspects regarding the role of sponges in the community reiterate a previous proposal (Cerrano et al., 2006) namely, that sponges are important reservoirs of biodiversity and that the phylum Porifera should be seriously considered in conservation programs.

\section{ACKNOWLEDGEMENTS}

We thank the taxonomy specialists for helping us with identifications of the associated fauna: Luciana Muguet (Bryozoa),
Cléo Oliveira (Mollusca), Juliana Bahia (Platyhelminthes), Carlos Renato R. Ventura and Fernanda Viana (Echinodermata), Daniela Barbosa (Ascidiacea), Paulo Paiva (Polychaeta) and Tereza G. Silva (Crustacea). We are thankful to Baslavi Condor and Paulo Paiva for their help in data analysis and to the anonymous referees for their suggestions that improved manuscript quality. We thank the Coordenação de Aperfeiçoamento de Pessoal de Nível Superior (CAPES), the Fundação Carlos Chagas Filho de Amparo à Pesquisa do Estado do Rio de Janeiro (FAPERJ) (E-26/111.541/2008), and the Conselho Nacional de Desenvolvimento Científico e Tecnológico (CNPq-480368/2008 2; CNPq/PIBIC-480368/ 2008 2) for grants and fellowships during this project.

\section{REFERENCES}

Abdo D.A. (2007) Endofauna differences between two temperate marine sponges (Demospongiae; Haplosclerida; Chalinidae) from southwest Australia. Marine Biology 152, 845-854.

AlertaRio S. (2011) Sistema AlertaRio, Prefeitura do Rio de Janeiro, RJ www.rio.rj.gov.br/alertario (accessed 10 August 2011).

Beaulieu S.E. (2001) Life on glass houses: sponge stalk communities in the deep sea. Marine Biology 138, 803-817.

Becerro M.A. (2008) Quantitative trends in sponge ecology research. Marine Ecology 29, 167-177.

Betancourt-Lozano M., Gonzalez-Farias F., Gonzalez-Acosta B. Garcia-Gasca A. and Bastida-Zavala J.R. (1998) Variation of antimicrobial activity of the sponge Aplysina fistularis (Pallas, 1766) and its relation to associated fauna. Journal of Experimental Marine Biology and Ecology 223, 1-18.

Bezerra L.E.A. and Coelho P.A. (2006) Crustáceos decápodos associados a esponjas no litoral do estado do Ceará, Brasil. Revista Brasileira de Zoologia 23, 699-702.

Biernbaum C.K. (1981) Seasonal changes in the amphipod fauna of Microciona prolifera (Ellis and Solander) (Porifera, Demospongia) and associated sponges in a shallow salt marsh creek. Estuaries 4 , $85-96$.

Bispo R., Johnsson R. and Neves E. (2006) A new species of Asterocheres (Copepoda, Siphonostomatoida, Asterocheridae) associated to Placospongia cristata Boury-Esnault (Porifera) in Bahia State, Brazil. Zootaxa 1351, 23-34.

Cerrano C., Calcinai B., Pinca S. and Bavestrello G. (2006) Reef sponges as host of biodiversity: cases from North Sulawesi. In Suzuki Y., Nakamori T., Hidaka M., Kayanne H., Casareto B.E., Nadao K., Yamano H. and Tsuchiya M. (eds), 1oth International Coral Reef Symposium Proceedings, Okinawa, 28 June-2 July 20o6. Functional roles of sponges in coral reefs. Tokyo: Japanese Coral Reef Society, pp. $208-213$.

Çinar M.E., Katagan T., Ergen Z. and Sezgin M. (2002) Zoobenthos inhabiting Sarcotragus muscarum (Porifera: Demospongiae) from the Aegean Sea. Hydrobiologia 482, 107-117.

Clavico E.E.G., Muricy G., da Gama B.A.P., Batista D., Ventura C.R.R and Pereira R.C. (2006) Ecological roles of natural products from the marine sponge Geodia corticostylifera. Marine Biology 148, 479-488.

Compagnone R.S., Oliveri M.C., Piña I.C., Marques S., Rangel H.R., Dagger F., Suárez A.I. and Gómez M. (1999) 5-Alkylpyrrole-2-Carboxaldehydes from the Caribbean sponges Mycale microsigmatosa and Desmapsamma anchorata. Natural Product Letters 13, 203-211. 
Cuartas E.I. and Excoffon A.C. (1993) La fauna acompañante de Hymeniacidon sanguinea (Grant, 1827) (Porifera: Demospongiae) Neotrópica 39, 3-10.

Dereczynski C.P., Oliveira J.S. and Machado C.O. (2009) Climatologia da precipitação no município do Rio de Janeiro. Revista Brasileira de Meteorologia 24, 24-38.

Duarte L.F.L. and Morgado E.H. (1983) Crustáceos parasitos de invertebrados associados à esponja Zygomycale parishii (Bowerbank) e ao briozoário Schizoporella unicornis (Jonhston, 1847). Iheringiasérie Zoologia 62, 3-11.

Duarte L.F.L. and Nalesso R. C. (1996) The sponge Zygomycale parishii (Bowerbank) and its endobiotic fauna. Estuarine, Coastal and Shelf Science 42, 139-151.

Fiore C.L. and Jutte P.C. (2010) Characterization of macrofaunal assemblages associated with sponges and tunicates collected off the southeastern United States. Invertebrate Biology 129, 105-120.

Frith D.W. (1976) Animals associated with sponges at North Hayling, Hampshire. Zoological Journal of the Linnean Society 58, 353-362.

Gravili C., Belmontea G., Cecere E., Denitto F., Giangrande A., Guidetti P., Longo C., Mastrototaro F., Moscatello S., Petrocelli A., Piraino S., Terlizzi A. and Boero F. (2010). Nonindigenous species along the Apulian coast, Italy. Chemistry and Ecology 26, $121-142$.

Huang J.P., McClintock J.B., Amsler C.D. and Huang Y.M. (2008) Mesofauna associated with the marine sponge Amphimedon viridis. Do its physical or chemical attributes provide a prospective refuge from fish predation? Journal of Experimental Marine Biology and Ecology 362, 95-100.

Ilan M., Ben-Eliahu M.N. and Galil B.S. (1994) Three deep water sponges from the eastern Mediterranean and their associated fauna. Ophelia 39, 45-54.

Jassby A.D. and Powell T.M. (1990) Detecting changes in ecological time series. Ecology 71, 2044-2052.

Johnsson R. (1998) Six new species of the genus Asterocheres (Copepoda: Siphonostomatoida) associated with sponges in Brazil. Nauplius 6, $61-99$.

Johnsson R. (2000) Spongiopsyllus adventicius new species and genus of Entomolepididae (Copepoda: Siphonostomatoida) associated with sponges in Brazil. Hydrobiologia 417, 115-119.

Johnsson R. (2002) Asterocherids (Copepoda; Siphonostomatoida) associated with invertebrates from California Reefs: Abrolhos (Brazil). Hydrobiologia 470, 247-266.

Klautau M., Monteiro L. and Borojevic R. (2004) First occurrence of the genus Paraleucilla (Calcarea, Porifera) in the Atlantic Ocean: P. magna sp. nov. Zootaxa 710, 1-8.

Klitgaard A.B. (1995). The fauna associated with outer shelf and upper slope sponges (Porifera, Demospongiae) at the Faroe Islands, Northeastern Atlantic. Sarsia 80, 1-22.

Koukouras A., Voultsiadou-Koukouras E., Chintiroglou H. and Dounas C. (1985) Benthic bionomy of the North Aegean Sea. 3. A comparison of the macrobenthic animal assemblages associated with 7 sponge species. Cahiers de Biologie Marine 26, 301-319.

Koukouras A., Russo A., Voultsiadou-Koukouras E., Dounas C. and Chintiroglou C. (1992) Relationship of sponge macrofauna with the morphology of their hosts in the North Aegean Sea. Internationale Revue der Gesamten Hydrobiologie 77, 609-619.

Koukouras A., Russo A., Voultsiadou-Koukouras E., Arvanitidis C. and Stefanidou D. (1996) Macrofauna associated with sponge species of different morphology. Marine Ecology-Pubblicazioni Della Stazione Zoologica Di Napoli 17, 569-582.
Lanna E., Monteiro L.C. and Klautau M. (2007) Life cycle of Paraleucilla magna Klautau, Monteiro and Borojevic, 2004 (Porifera, Calcarea). In Custódio M.R. Lôbo-Hajdu G. Hajdu E. and Muricy G. (eds) Porifera research-biodiversity, innovation and sustainability. Rio de Janeiro: Museu Nacional-Série Livros 28, pp. 413-418.

Legendre P. and Gallagher E. (2001) Ecologically meaningful transformations for ordination of species data. Oecologia 129, 271-280.

Long E.R. (1968) The associates of four species of marine sponges of Oregon and Washington. Pacific Science 22, 347-351.

Longo C., Mastrototaro F. and Corriero G. (2007) Occurrence of Paraleucilla magna (Porifera: Calcarea) in the Mediterranean sea. Journal of the Marine Biological Association of the United Kingdom $87,1749-1755$.

Ludwig J.A. and Reynolds J.F. (1988) Statistical ecology-a primer on methods and computing. New York: Wiley-Interscience.

Magnino G., Pronzato R., Sarà A. and Gaino E. (1999) Fauna associated with the horny sponge Anomoianthella lamella Pulitzer-Finali \& Pronzato, 1999 (Ianthellidae, Demospongiae) from Papua-New Guinea. Italian Journal of Zoology 66, 175-181.

Marinho P.R., Moreira A.P.B., Pellegrino F.L.P.C., Muricy G., Bastos M.C.F., Santos K.R.N, Giambiagi-deMarval M. and Laport M.S. (2009) Marine Pseudomonas putida: a potential source of antimicrobial substances against antibiotic-resistant bacteria. Memórias do Instituto Oswaldo Cruz, Rio de Janeiro 104, 678-682.

Marinho P.R., Muricy G.R.S, Silva M.F.L., deMarval M.G. and Laport M.S. (2010) Antibiotic-resistant bacteria inhibited by extracts and fractions from Brazilian marine sponges. Brazilian Journal of Pharmacognosy 20, 267-275.

Mladenov P.V. and Emson R.H. (1988) Density, size structure and reproductive characteristics of fissiparous brittle stars in algae and sponges: evidence for interpopulational variation in levels of sexual and asexual reproduction. Marine Ecology Progress Series 42, 181-194.

Morgado E.H. and Tanaka M.O. (2001) The macrofauna associated with the bryozoan Schizoporella errata (Walters) in southeastern Brazil. Scientia Marina 65, 173-181.

Nalesso R.C., Duarte L.F.L., Pierozzi I. and Enumo E.F. (1995) Tube epifauna of the Polychaete Phyllochaetopterus socialis Claparède. Estuarine, Coastal and Shelf Science 41, 91-100.

Neves B.M., Lima E.J.B. and Pérez C.D. (2007) Brittle stars (Echinodermata: Ophiuroidea) associated with the octocoral Carijoa riisei (Cnidaria: Anthozoa) from the littoral of Pernambuco, Brazil. Journal of the Marine Biological Association of the United Kingdom $87,1263-1267$.

Neves G. and Omena E. (2003) Influence of sponge morphology on the composition of the polychaete associated fauna from Rocas Atoll, northeast Brazil. Coral Reefs 22, 123-129.

Pearse A. S. (1950) Notes on the inhabitants of certain sponges at Bimini. Ecology 31, 149-151.

Peattie M. E. and Hoare R. (1981) The sublittoral ecology of the Menai Strait. 2. The sponge Halichondria panicea (Pallas) and its associated fauna. Estuarine, Coastal and Shelf Science 13, 621-635.

Ribeiro S.M., Omena E.P. and Muricy G. (2003) Macrofauna associated to Mycale microsigmatosa (Porifera, Demospongiae) in Rio de Janeiro State, SE Brazil. Estuarine, Coastal and Shelf Science 57, 951-959.

Rützler K. (1976) Ecology of Tunisian commercial sponges. Tethys 7 , 249-264.

Santos O.C.S., Pontes P.V.M.L., Santos J.F.M., Muricy G., Giambiagi-deMarval M. and Laport M.S. (2010) Isolation, characterization and phylogeny of sponge-associated bacteria with antimicrobial activities from Brazil. Research in Microbiology 161, 604-612. 
Serejo C.S. (1998) Gammaridean and caprellidean fauna (Crustacea) associated with the sponge Dysidea fragilis Johnston at Arraial do Cabo, Rio de Janeiro, Brazil. Bulletin of Marine Science 63, 363-385.

Skilleter G.A., Russell B.D., Degnan B.M. and Garson M.J. (2005) Living in a potentially toxic environment: comparisons of endofauna in two congeneric sponges from the Great Barrier Reef. Marine Ecology Progress Series 304, 67-75.

Sokal R.R. and Rohlf F.J. (1995) Biometry. San Francisco, CA, Freeman \& Co.

Stofel C.B., Canton G.C., Antunes L.A.S. and Eutrópio F.J. (2008) Fauna associada à esponja Cliona varians (Porifera, Demospongiae) Natureza Online 6, 16-18.

Villamizar E. and Laughlin R.A. (1991) Fauna associated with the sponges Aplysina archeri and Aplysina lacunosa in a coral reef of the Archipiélago de Los Roques, National Park, Venezuela. In Reitner J. and Keupp H. (eds) Fossil and recent sponges. Berlin: Springer, pp. $522-542$.

Wendt P.H., van Dolah R.F. and O'Rourke C.B. (1985) A comparative study of the invertebrate macrofauna associated with seven sponge and coral species collected from the South Atlantic Bight. Journal of the Elisha Mitchell Scientific Society 101, 187-203.

Westinga E. and Hoetjes P.C. (1981) The intrasponge fauna of Spheciospongia vesparia (Porifera, Demospongiae) at Curaçao and Bonaire. Marine Biology 62, 139-150.

Wulff J.L. (2006) Ecological interactions of marine sponges. Canadian Journal of Zoology 84, 146-166.

and

Zammit P.P., Longo C. and. Schembri P.J. (2009) Occurrence of Paraleucilla magna Klautau et al., 2004 (Porifera: Calcarea) in Malta. Mediterranean Marine Science 10, 135-138.

\section{Correspondence should be addressed to:} Michelle Klautau

Universidade Federal do Rio de Janeiro, Instituto de Biologia, Departamento de Zoologia, Avenida Carlos Chagas Filho, 373, CEP 21941-902, Rio de Janeiro, RJ, Brazil e-mail: mklautau@biologia.ufrj.br 